\title{
The Siren Song of History: Originalism and the Religion Clauses
}

Jeffrey Shulman

Georgetown University Law Center, shulmanj@law.georgetown.edu

Georgetown Public Law and Legal Theory Research Paper No. 11-130

This paper can be downloaded free of charge from:

https://scholarship.law.georgetown.edu/facpub/696

http://ssrn.com/abstract=1947033

27 J. L. \& Relig. 101 (2011)

This open-access article is brought to you by the Georgetown Law Library. Posted with permission of the author. Follow this and additional works at: https://scholarship.law.georgetown.edu/facpub

Part of the Constitutional Law Commons, Public Law and Legal Theory Commons, and the Religion Law Commons 


\title{
REVIEW ESSAY
}

\author{
THE SIREN SONG OF HISTORY: \\ ORIGINALISM AND THE RELIGION CLAUSES \\ Reviewed by Jeffrey Shulman*
}

The Forgotten Founders on RELIGION AND PUbLIC LIFE. Edited by Daniel L. Dreisbach, Mark David Hall and Jeffrey H. Morrison. Foreword by Mark A. Noll. University of Notre Dame Press 2009. Pp. 316. ISBN: 0-268-02602-5;

CHURCH, STATE, and ORIGINAL INTENT. By Donald L. Drakeman. Cambridge University Press 2010. Pp. 371. ISBN: 0-521-11918-9;

God and the Founders: MAdison, WASHINGTON, AND JEFFERSON. By Vincent Phillip Muñoz. Cambridge University Press 2009. Pp. 242. ISBN: 0-521-51515-7.

\section{Happy people have no history. \\ Leo Tolstoy \\ (quoting a French proverb)}

It is said that we are all originalists now. No doubt some of us are more faint-hearted than others, but originalism has blossomed into so many versions of its original self that there is room for everyone at the party. ${ }^{1}$ The attraction of originalist scholarship to legal professionalslaw professors and jurists alike-raises especially interesting questions. While a few legal professionals are historical scholars of a high order, most are content to be second-hand historians, their scholarship borrowed to serve other academic interests or the demands of legal advocacy. Donald Drakeman observes that the work of the Supreme

\footnotetext{
* Associate Professor, Legal Research and Writing, Georgetown Law, Washington, D.C. Professor Shulman's most recent articles include Epic Considerations: The Speech That the Supreme Court Would Not Hear in Snyder v. Phelps, 2011 CARDOZO L. Rev. DE NOVO 35 (2011); The Parent as (Mere) Educational Trustee: Whose Education Is It, Anyway?, 89 NEB. L. REV. 290 (2010); and Free Speech at What Cost: Snyder v. Phelps and Speech-Based Tort Liability, 2010 CARDOZO L. REV. DE NOVO 313 (2010).

1. See, e.g., Thomas B. Colby \& Peter J. Smith, Living Originalism, 59 Duke L.J. 239 (2009).
} 
Court has been based often on "widely read and highly regarded histories [written by scholars] whose craft had not yet developed the dedication to nuance, to cultural frame of reference, or to the degree of objectivity expected of historians seeking tenure in twenty-first-century academia." (147) No doubt, this observation is true enough, and nowhere more so than when the Court has been faced with questions of religious freedom; but it suggests that a sophisticated historical scholarship will help legal professionals reach a more reliable understanding of the original meaning of the Religion Clauses. Alas, historical reliability is not likely to be of much value to the legal professional.

Indeed, there is an almost certain guarantee that the muse of history is not going to help those who want the Religion Clauses to stand for something determinate, at least for something determinate enough to serve a heuristic purpose in legal controversy. ${ }^{2}$ Dedication to nuance (a word, by the way, etymologically related to shadows and obscurity) will be little appreciated by those who assume that Clio promises her suitors a clear jurisprudential pathway. The works reviewed here remind us that history is a fickle hermeneutical mistress; she may appear charming in her simplicity, but, in fact, she is a most complex and unreliable creature, rarely a firm foundation for legal argument or doctrinebuilding. What did the Religion Clauses mean to the eighteenth century? Most likely as many things as they mean to us today.

The collection of brief biographical essays that compose The Forgotten Founders on Religion and Public Life reminds us that "it is artificial to limit 'the founders' to a few individuals." (x) More specifically, the essays are meant to "make a difference in helping Americans in the twenty-first century understand the complex role of religion in our nation's first years." (xi) The "vital role [religion played] in the American founding project" is complex in a way that an overemphasis on a relatively few founders cannot capture. (xiii) What the collection is not meant to be is a polemical effort to ballast the

2. On the use and abuse of historical evidence in Establishment Clause controversy, see, e.g., Steven K. Green, "Bad History": The Lure of History in Establishment Clause Adjudication, 81 Notre Dame L. ReV. 1717 (2006); Steven G. Gey, More or Less Bunk: The Establishment Clause Answers That History Doesn't Provide, 2004 BYU L. REv. 1617 (2004). Cf., e.g., Christopher L. Eisgruber, The Living Hand of the Past: History and Constitutional Justice, 65 Fordham L. REV. 1611, 1622 (1997); and Daniel L. Dreisbach, Everson and the Command of History: The Supreme Court, Lessons in History, and the Church-State Debate in America, in EVERSON REVISITED: RELIGION, EdUCATION, AND LAW AT THE CROSSROADS 23-57 (Jo Renée Formicola \& Hubert Morken eds., Rowman \& Littlefield 1997). See generally DANIEL A. FARBER \& SUZANNA SHERRY, DESPERATEly SEEKING CERTAINTY: THE MisGuided QueST FOR CONSTITUTIONAL Foundations (Univ. Chi. Press 2002). 
historical record by describing the views of the religiously inclined forgotten founders. To make this point, Mark Noll points to "the complexity of what the authors achieve":

By broadening the notion of "the founders," they draw in individuals who promoted a quite different kind of deism (Thomas Paine, author of the decisive piece of propaganda, Common Sense), or who adhered to a quirky individual religion (the Philadelphia physician Benjamin Rush), or who maintained a moderate Anglican position (the Virginia jurist and first U.S. Attorney General, Edmund Randolph). The historical payoff from studying a broad group of founders is to enrich rather than simplify our picture of what the founders "believed." (x)

It is true that a broadened notion of "the founders" achieves this complexity, but the volume's historical payoff would have been rich enough had the editors put aside the decisively different Paine, the theistic Hamilton, and the quirky Rush. For the resulting picture would have provided a more coherent reminder of the compelling place that traditional religiosity occupied in the lives of many of the men and women who contributed mightily to our nation's ideological origins. Even as the collection stands, it is hard not to see it as a polemical contribution, if a somewhat faint-hearted one, to the debate about the religious world of our founding fathers. In fact, this contribution is the collection's real strength.

One might question the editors' premise that "there has long been a tendency to discount or ignore the role of religion in the American founding in general." (xiii) Or, at least, whether this tendency has not been sufficiently corrected. But assuming the premise to be true, these essays operate as a corrective to what the editors refer to as "religious illiteracy" among secular scholars. (xiv) The strength of the collection lies not in its complexity, but in its effort to draw attention to a religious consensus that receives too little academic interest. By providing a broader definition of "founder" - a definition that allows for the inclusion of Abigail Adams, Samuel Adams, Oliver Ellsworth, Alexander Hamilton, Patrick Henry, John Jay, Thomas Paine, Edmund Randolph, Benjamin Rush, Roger Sherman, and Mercy Otis Warrenand thus by providing a more complete picture of the founders' views, the collection hopes to bring to the historical foreground a set of themes that form a significant part of the country's foundational beliefs.

What Edith Gelles says of Abigail Adams might be said of most of the figures we encounter in these essays: "Belief was like the air she breathed; it surrounded her and was taken for granted as a truth that 
sustained life." (30) The commonplace-ness of deep religious belief perhaps has contributed to its being taken for granted in scholarly circles, and if all this collection did was to show that religion was important to the founders, forgotten and non-forgotten alike, it would be worthy of note. But time and again more particular thematic notes resound through these biographies. Above all, the lives discussed here (most of them, at any rate) testify to a prevailing providentialism. All of life was considered providential to Abigail Adams. "[N]othing occurred except by the will of God." (31) Such abiding trust in God's providence not only provided comfort and assurance in times of personal crisis (it was a time when sparrows fell with inconceivable frequency), but this same trust was the hallmark of the common political vision that America was the special object of divine solicitousness. In our post-modern, post-colonial times, we may take such sentiments as little more than congratulatory imperial rhetoric. For substance, we look to serious political theorists (even such "forgotten" ones as Vattel, Grotius, Sydney, Beccaria, or Pufendorf). The point of this collection is that we pay insufficient attention to the substantive biblical and theological milieu within which many of the founders lived - and within which they waged revolution.

The note of providentialism is heard in almost every entry. For John Jay, the career of American independence and nation-building came about by the 'great plan of Providence." (146) In this respect, America was thought of as special. The new nation was uniquely committed to moral principles consistent with the divine plan, uniquely positioned to serve as an example of divine purpose. Rosemarie Zagarri writes that Mercy Otis Warren "maintained that God had played a special role in enabling Americans to secure their freedom and establish the United States as a beacon of liberty to other nations in the world." (285) Similarly, Gary Smith describes how Samuel Adams expected 'that God would 'erect a mighty empire in America' characterized by biblical morality and manners and zealous efforts to spread liberty and Christianity to the world." (50) Indeed, rationalism and republicanism could co-exist with a fervid moral millenarianism, as in the case of Benjamin Rush. By Rush's lights, as Robert Abzug tells us, "America, if it fulfilled its mission, would lead the world to the Second Coming prophesied by the Great Awakening." (227-28) The new order of the ages required a new republican virtue, even if that meant, for Rush, a system of education that was designed to "convert men into republican machines." (232) 
The linkage of liberty and Christianity, of religion and the republic, was the essence of a new American exceptionalism. For God's protection of the new nation's freedom was tightly connected to moral concerns. The providential vision was in part a legacy of the Puritan covenantal tradition. God's blessing was not unconditional: His new kingdom on earth required a revolution in moral righteousness as well as in political rights. From the font of providentialism flowed a sense of the critical importance of Christian virtue; from Puritanism, a sense of its fragility. Rectitude, Samuel Adams argued, "would forever be 'the Soul of a Republican Government." (48-49) And religion was the soul of rectitude. Patrick Henry failed in his bid to obtain a general assessment to support religious teaching - and we have come to see Madison and Jefferson as the true progenitors of our religious freedom - but, as Thomas Buckley reminds us, Henry had excellent company in thinking that religion was the virtual ingredient of a virtuous society, both among non-forgotten founders (like Washington and Adams) and the probably forgotten (like Richard Henry Lee). (138-39) Righteousness alone, Henry wrote, can exalt a nation. (139) Even Alexander Hamilton at his most deistic declared, as Gregg Frazer writes, that religion was one of the "venerable pillars that support the edifice of civilized society." (114) And when license replaced liberty, when religion and morality assumed separate posts, the blessings of divine providence would be withdrawn - and the hope of a Christian Sparta (this vision belonged to Samuel Adams (49)) would be lost. "People were "not worth saving," Adams wrote, "if they 'lost their virtue." (49) The irreligious French Revolution provided salutary notice of this possibility.

This picture of religious consensus does more than flesh out the historical portrait of the founding times. It should have an impact on contemporary political and legal debates. At a broad level, as William Casto observes in his chapter on Oliver Ellsworth, it calls into question some of the basic operating assumptions of originalist historiography, at least where the Religion Clauses are concerned.

[O]ne conclusion should be clear: justices and scholars who wish to understand the founders' views on religious liberty and churchstate relations should not limit themselves to particular founders whose views happen to support a particular twenty-first-century political agenda.... James Madison and Oliver Ellsworth - both critical framers of the First Amendment-had significantly different views regarding the proper relationship between church and state. Given this clear disparity, no one should pretend that 
either man's carefully thought-out views represent those of the entire founding generation. (93-94)

Mark Hall makes the same point in his chapter on Roger Sherman. Noting Sherman's belief "that Christianity was necessary for political prosperity," (266) Hall concludes that as a matter of historical scholarship this view has not received its due.

Sherman's approach to religious liberty and church-state relations may seem parochial today. If, however, the founders' views are relevant for contemporary jurisprudence, then there is no good reason for preferring those of Thomas Jefferson ... over Sherman's. Moreover, an excellent argument can be made that Sherman is more representative of the founders with respect to these issues than Jefferson. (270)

History records that though Jefferson offered moral support (with his famous letter proposing "a wall of separation of church and state") to the Baptists who petitioned the Connecticut state legislature for greater disestablishment, it was Oliver Ellsworth's endorsement of state support for religious entities that prevailed. Ellsworth was chair of the committee tasked by the Connecticut General Assembly with considering the separationist petition. The committee's report, published under Ellsworth's sole signature, concluded that every member of society should support religious institutions for the secular good they do. After all, religion is, as Ellsworth wrote, "wisely calculated to direct men to the performance of all the duties arising from their connection with each other, and to prevent or repress those evils which flow from unrestrained passion." (74)

These brief biographies challenge us to broaden our historical focus. The real payoff in doing so comes from a greater familiarity with founders who espoused beliefs about church and state that were commonly held by members of the founding generation, views that ought to be a part of the great debate concerning the meaning of the Religion Clauses. One can always quibble with the choice of figures selected for inclusion in such a volume, ${ }^{3}$ but I think this volume would have been stronger had it been more single-mindedly the historical ballast that it was not supposed to be. To a large extent, this is the thematic thrust of The Forgotten Founders on Religion and Public Life, and to that extent it enriches our understanding of the role that religion played in the country's founding. This role was also played by more

3. For another list of forgotten founders, see MichaEl NovaK, On Two Wings: Humble FAITH AND COMMON SENSE AT THE AMERICAN FOUNDING 127-58 (Encounter Books 2002). 
overtly religious forgotten voices, like that of the evangelical dissenter Isaac Backus. Given the strict separationist views of religious nonconformists (working in the tradition of Roger Williams), the inclusion of a fitting representative would have gone a long way toward showing that even within the religious consensus of the eighteenth century there was complexity enough.

Of course, Jefferson's wall would be constructed-and then deconstructed - by the Supreme Court. In both efforts, the Court turned to the non-forgotten founders for support. In his study of the process by which the Court created its high and impregnable wall, Donald Drakeman argues that " $[\mathrm{t}] \mathrm{o}$ date, establishment clause jurisprudence clearly owes a considerable debt to Whiggish myth-making by a number of respected historians in the nineteenth and early twentieth centuries." (11-12) An illuminating history of bad history, Church, State, and Original Intent is really two books in one: It is 1) a critique of the Supreme Court's early Establishment Clause jurisprudence, a critique that opens a fascinating historical window on how the Court succumbed to the temptations of law office history; and 2) an argument that, despite the opacity of the historical materials we have to work with, it is possible "to paint a reasonably clear picture of what was going on when the First Congress had its brief and desultory debate on the establishment clause." (196) Accordingly, Drakeman sets out to answer two questions critical to a proper understanding of the Establishment Clause:

(1) Why did the Supreme Court pursue this quest for the First Amendment's original meaning, and once it did, where did the justices find the history they have so firmly grafted onto the text of the establishment clause? (2) What is a reasonable originalistic interpretation of the establishment clause in light of all of the relevant materials? (vii)

In response to the first question, Drakeman has produced a rich and engaging study of the uses of history made by the Supreme Court in the seminal cases of Reynolds v. United States (1879) and Everson v. Board of Education (1947). Drakeman's second question ("What is a reasonable originalistic interpretation of the establishment clause ...?") already answers the work's most interesting theoretical quandary: Can the Supreme Court's opinions with regard to the Religion Clauses "flow naturally and unimpeded from the mandates of the historical record"? (148) In other words, can history provide a clear path through the complexity? Well, apparently, good history can. 
Whether or not this is the right answer, it produces a work that effectively sidesteps a searching look at the premises of the originalist enterprise. Drakeman spends a worthy chapter on "the explosion of scholarly literature" (148) that, in his words, has amounted to a battle for the historical high ground, a battle that has had no clear victor. But he leaves relatively unaddressed the concern that the battle may be all for naught. In other words, the net result of Drakeman's inquiry is that his history is the historical high ground. It turns out that the meaning of the Establishment Clause is not historically indeterminate. In fact, it turns out that the lack of historical clues to the meaning of the Establishment Clause is the clue we have been looking for all along.

Drakeman provides a rich and engaging study of Reynolds and Everson. In these cases, the Supreme Court "located the heart of the First Amendment's religion clauses in what we might now call the ardently strict separationist branch of the church-state debate." (63) Drakeman's study of these cases is a fascinating exercise in intellectual archaeology, tracing the roots that doctrinal, and sometimes personal, biases took to arrive at a Virginia-centric reading of the Religion Clauses. It was Chief Justice Morrison Waite's decision in Reynolds that "had the effect of essentially writing Thomas Jefferson and James Madison directly into the First Amendment." (21) Drakeman traces the historical lineage from Justice Waite to George Bancroft, the preeminent nineteenth-century historian (and, perhaps equally important, neighbor to the chief justice). Bancroft directed Waite to the Old Dominion, and the rest is, as they say, history: "Once directed to Virginia by Dr. Bancroft, the chief justice came under the direct influence of two native Virginian historians, Robert B. Semple and Robert R. Howison. These historians shared the view that the Old Dominion was indeed the font of American freedoms." (22)

Drakeman is particularly sensitive to how easily history is infected by ideology of various stripes. Semple and Howison "also happened to be Baptist and Presbyterian ministers whose ardent opposition to ecclesiastical establishments was inspired by the dissenting churches' persecution at the hands of a legally established church." (22-23) Thus, for these makers of history, as well as for the makers of law who relied on their research, the Jefferson-Madison historical legacy came to stand for a consensus on the principle of strict separationism, a principle culled from writings with a specific anti-establishment purpose (Madison's Memorial and Remonstrance against Religious Assessments and Jefferson's Bill for Establishing Religious Freedom). Waite's task was to craft an opinion that both remained true to what Drakeman calls 
these "odes to religious liberty" (63) and sustained Mr. Reynolds's conviction, against a religious freedom defense, under federal law outlawing plural marriages in the territories. It is Drakeman's contention that Waite could have relied on other prominent sources "that not only would have amply supported the conclusion he needed to reach - that is, that the bigamy conviction be upheld - but, as raw material for future law office historians, could have taken the establishment clause in a very different direction." (64) It is not clear why Waite did not reach out to other commentators on the Constitution with which he was familiar, some of whom proffered the notion so prevalent in the biographies of the forgotten founders: that religion can and should receive encouragement from the state. What is clear, to Drakeman, is that Waite's choice - the fact that Waite "fell under the influence of disestablishment historians whose fellow Baptists and Presbyterians, to gain political advantage in their battles against Virginia's establishment, embraced the bills of the 'infidel' Jefferson and rescued Madison's Memorial and Remembrance from relative political obscurity" (72) — set the Supreme Court on a course toward strict separationist doctrine, a course that would evolve into "irresistible dogma." (71) In future Establishment Clause cases, the justices would choose among different readings of the Jefferson-Madison legacy, ignoring the competing legacy of a tribe of forgotten founders.

Drakeman ultimately acquits Waite of writing law office history, resting what culpability there is for constructing history on a biased platform with the historians Waite consulted, who "took the church-state question down a somewhat more narrow path than it deserved." (73) $\mathrm{He}$ is less charitable with regard to the work of Justices Hugo Black and Wiley Rutledge in the Everson case. Here, Drakeman contends, the justices quite consciously conflated historical mythmaking and constitutional doctrine-making. Again, Drakeman provides a rewarding, if sometimes dispiriting, account of opinion-writing dynamics. Again, Drakeman finds that history-specifically, the history of Virginia at its revolutionary and nation-building moments-became the stuff of "creation myth." (82) As Drakeman tells the story, "first Rutledge and then Black set off on a premeditated search-and-employ mission to locate historical events" that would serve their doctrinal purposes. (7980) As in Reynolds, so in Everson professional historians aided and abetted the justices' efforts via a goal-oriented, Whiggish approach to historical interpretation. (80) But it was not just that this history was infected with historiographical bias. Drakeman makes the case-with appropriate caution - that the Court's first reading of the Establishment 
Clause was influenced by the Protestant predispositions of the Court.

The views of the justices and the historians they consulted reflected... mid-twentieth-century liberal intellectuals' fears of any form of authoritarianism, especially Roman Catholicism as "antagonistic to the "democratic way of life." ... It is little wonder that in this cultural context Madison's and Jefferson's "strict separationist" writings would provide an appealing intellectual and constitutional pedigree for a Court anxious to protect critical democratic institutions, especially the schools, from the sectarian threat that could be unleashed by a breach in the wall of separation. (80-81)

Nonetheless, Drakeman looks upon the Everson opinion with some compassion. Today, he writes, it is easy to see the limitations of hyperWhiggish historical narrative and hagiographic biography. Black and Rutledge, like Waite before them, could only work with the materials they had at hand, and what they had were widely read and highly regarded histories written by scholars whose craftsmanship had not yet reached the heights of today's paragons of nuance. (147-48) (This is a bit of Whiggish metahistory, I suppose. One wonders how future generations of historians will view the craft of today's practitioners.)

But for years a cottage industry dedicated to the originalist craft has been setting the Establishment Clause record straight. The fact that this mighty jousting between strict separationist and nonpreferentialist camps has more or less resulted in a draw, however, does not deter Drakeman from entering the fray.

Part of the difficulty the historian of the Religion Clause faces is the nature of the evidence. Drakeman goes beyond the non-forgotten founders to consider a wide range of historical materials, yet the historical background remains frustratingly murky. It is Drakeman's trick to make clarity out of lack of clarity. For Drakeman, the most striking and significant piece of evidence as to the original meaning of the Establishment Clause is the lack of historical evidence. Had the Establishment Clause been meant to embody either a strict separationist or nonpreferentialist point of view, Drakeman argues, the hue and cry from the opposing camp would not have been missed. We know what people were saying about the Establishment Clause at the time it was adopted and ratified — and, Drakeman claims, they were saying nothing.

It is Holmes who best understands the meaning of this silence. Not Oliver Wendell, but Sherlock Holmes. The dog, you see, didn't bark. From the striking lack of commentary, let alone protest, on the part of those who were there at the creation, Drakeman concludes that the 
Establishment Clause meant only that Congress should be prohibited from establishing a national religion. The First Amendment succeeded "in turning the hotly contested subject of church-state relations-which had already caused legislative battles in the states and would continue to do so virtually in perpetuity-into a 'milk and water' amendment by focusing on the one thing no one wanted and everyone could unite against: a "Church of the United States."' (260) The clause was not meant to embody broad substantive values, (260-61) nor was it meant to shield state-level establishments from federal meddling. (329) Drakeman takes no position on whether the Fourteenth Amendment incorporates the Establishment Clause, but it hardly matters. At the time of the Fourteenth Amendment, Drakeman contends, the only shared meaning of the Establishment Clause remained that it "was designed to forbid a "national religion."' (321)

With Vincent Muñoz's God and the Founders: Madison, Washington, and Jefferson, we return full bore to the non-forgotten founders. But, as this work details, there is diversity enough in Muñoz's founding triumvirate. Muñoz chooses not to enter the originalism fray directly. Elsewhere, Muñoz has addressed the original meaning of the Religion Clauses; ${ }^{4}$ here, he is content to address the question indirectly, by providing a nuanced reading of the views held by three notable "fathers" of the Constitution. Of course, as Muñoz notes, this project does have implications for originalist arguments. Whatever flavor of originalism one ascribes to, the views of Madison, Washington, and Jefferson are important. But Muñoz's contribution to the originalist debate is actually quite direct, if only implicitly so. It is Muñoz's position that "none of these Founders embraced strict separationism or nonpreferentialism as those positions are typically understood." (3) More to the point, Muñoz argues that Madison, Washington, and Jefferson - all advocates of religion as a natural right (6-7) — “disagreed about the separation of church and state and embraced different understandings of the right to religious liberty." (3) On such a ground, Muñoz might have been led to believe that a quest for the original meaning of the Religion Clauses is "both futile and misdirected." There may be multiple and contradictory original meanings. There may

4. Vincent Muñoz, The Original Meaning of the Free Exercise Clause: The Evidence from the First Congress, 31 HARV. J.L. \& PUB. POL'Y 1083 (2008); Vincent Muñoz, The Original Meaning of the Establishment Clause and the Impossibility of Its Incorporation, 8 UNIV. PA. J. CONST. L. 585 (2006).

5. See Daan Braveman, The Establishment Clause and the Course of Religious Neutrality, 45 MD. L. REV. 352, 375 (1986) (“[A] literal quest for the Framers' intent may be both futile and misdirected."). 
be an original meaning that is little more than an indecipherable compromise among original meanings.

But historical indeterminancy is not the prevailing theme here. Whatever ambiguities are to be located within the history of the Establishment Clause, Muñoz sets out to determine the apparently unambiguous views of each founder not only on the broadest questions of religious liberty, but on the narrower point of specific church-state doctrinal controversies. Muñoz's goal is threefold: 1) to describe the founders' "different understandings of the right to religious freedom"; 2) "to extrapolate legal doctrines from the church-state philosophies of each Founder"; and 3) "to explain how the Founders' different positions would have adjudicated actual cases that have come before the Supreme Court." (8) In short, Muñoz's project is to "set the historical record straight." (3)

In this regard, he opposes himself to originalists who presume "that each provision of the Constitution has one definitive original meaning and that that meaning should govern contemporary constitutional disputes." (2) Muñoz assumes, nonetheless, that there is one definitive original Madisonian or Washingtonian or Jeffersonian view of the Religion Clauses. But which Madison are we talking about: the advocate of the Memorial and Remonstrance, the president who issued a prayer proclamation during the War of 1812, or the more detached Madison of the Detached Memoranda? Which Washington? Which Jefferson? Even if we could draw a coherent picture of Madison's (or Washington's or Jefferson's) view of the Religion Clauses, how do we leap the chasm from theory to practice? This is a project, if I may borrow from Stephen Smith, foreordained to failure. ${ }^{6}$ Perhaps "failure" is too strong. We simply have no way of evaluating the conclusions reached by such a speculative and circuitous route. However interesting the conclusions, they remain, in effect, the result of a mere thought experiment.

In Muñoz's view, Madison emerges as a champion of a "religious blind" constitution, a constitution that prohibits the state from taking cognizance of religion, favorably or otherwise. This is neither the Madison favored by the strict separationists nor the Madison preferred by the nonpreferentialists. For Muñoz, Madison embraces what is essentially a church-state non-discrimination principle.

6. See generally STEPHEN D. SMITH, ForeORDAINED FAILURE: THE QuEST FOR A CONSTITUTIONAL PRINCIPLE OF RELIGIOUS FREEDOM (Oxford Univ. Press 1995). 
A Madisonian approach to the First Amendment, accordingly, would require the state to remain noncognizant of religion. The government could not use religion as a basis for classifying citizens. Religion as such could not be the cause of state action, be the subject of criminal sanctions or governmental regulations, or be used to determine eligibility for governmental benefits. To borrow from contemporary civil rights discourse, the Madisonian position would require the state to remain "religion blind." (121)

A Madisonian approach to the First Amendment, Muñoz thus concludes, would not only allow indirect burdens that are the product of neutral and generally applicable laws, but "would prohibit all religiously based exemptions from such laws, whether by the judiciary or by ordinary legislation." (179)

While Madison wanted to create a governmental blueprint that would take no notice of religion, Washington sought "to use governmental authority to encourage religion and to foster the religious character of the American people." (50) For Washington, Muñoz writes, state support of religion was less about freedom of conscience than about civic stability and prosperity. Washington's position was that "[g]overnment should support religion because religion supports republican government." (59)

It would be more accurate to say that Washington's position was that government should support religion when religion supports government, for Washington was prepared to encourage only those religious practices that were consistent with "the legitimate duties of republican citizenship." (50) If "a pious citizenry was indispensable to republican government," (50) a zealous citizenry was all too likely to advocate behavior that, in Washington's view, would be contrary to good citizenship. (60-61) Whatever Madison may have meant when he wrote that religious duty is precedent to the claims of civil society, Washington was not prepared to make civic responsibility secondary to other duties. For Washington, Muñoz writes, "the obligations of good citizenship ... stand as a precondition for one's rights to be secured." (61) Thus, because the state is under no affirmative obligation to tolerate actions opposed to good citizenship, the state "may legitimately expect all citizens to perform the reasonable duties of citizenship, even those that religious citizens find objectionable." (60) Under a Washingtonian approach to the First Amendment, religionists enjoy no right to exemptions from general law, and legislative accommodations ought to be limited by prudential concerns. In Muñoz's assessment, "Washingtonianism would not prohibit or grant exemptions from 
indirect burdens on religious practices as long as the state action burdening religion furthered a legitimate civic interest." (179)

Muñoz's chapter on Jefferson's view of religious liberty presents some especially interesting conclusions. Noting the contradiction between Jefferson's professed philosophy of religious freedom as a natural right and his actual political practice (particularly, his opposition to clerical influences on social and educational policy), (72-73) Muñoz suggests that this tension can be explained as a feature of Jefferson's developmental or progressive view of religious freedom.

Jefferson seems to have believed that different levels of religious freedom were appropriate for different stages of political and societal development. He championed the idea that individuals possessed natural rights of religious freedom and that a just society should aspire to protect those rights. At the same time, he did not believe that society could extend all the rights of religious freedom to religious clergy as long as clergy threatened the rights and freedoms of others. The "establishment" of religious freedom, as Jefferson called it, first required freedom from clerical influence in American society and then, and only then, securing in practice the natural rights of religious liberty. Jefferson's developmental view of religious freedom meant that the degree to which religious liberty could be protected depended on the level of rational development society had achieved. (73)

As evidence of the "progressive nature of [Jefferson's] project," (73) Muñoz moves from political philosophy to what we might call Jefferson's political pedagogy. According to Muñoz, Jefferson's educational plan "reflect[s] his intention to move the religious views of the new nation away from ecclesiastical sectarianism toward a more generic nondenominationalism." (110) Education was one way to harness the power of the state in the interest of "nutur[ing] the rational religious beliefs that [Jefferson] believed supported reason and freedom and to suppress the irrational dogmas and institutions that he believed to be hostile to liberty." (116) That Jefferson's vision of civil liberties had its darker side is not a new observation, ${ }^{7}$ but Muñoz provides a useful reminder that one founder's enlightenment may well be another's religious Dark Age. It is not surprising that a Jeffersonian approach to the Religion Clauses, in Muñoz's estimation, would favor religion the least. (189)

7. See, e.g., LeONARD W. LeVy, JefFerson AND CIVIL Liberties: The DARKer Side (Belknap Press 1963); David Tyack, Forming the National Character: Paradox in the Educational Thought of the Revolutionary Generation, 36 HARV. EDUC. REV. 29 (1966). 


\section{$* \quad * \quad *$}

It is hard to foresee much happiness in the lot of those seeking the original meaning of the Religion Clauses. We may acknowledge the opacity of the historical record, the variety of viewpoints held by founders forgotten and non-forgotten, the humanness of founders who did not always practice what they preached, even the basic indeterminancy of language; still, we are seduced by the siren song of interpretive certainty. But the search for greater clarity is not without its payoff. As the three books under review here illustrate, the more we look for answers in the historical record, the more we are likely to find ambiguity - and with each step we take away from the promised land of historical clarity, we move a step closer to the richer, if less certain, terrain of historical truth. 